\title{
Targeting inflammatory pathways to treat atherosclerosis and cancer
}

\begin{tabular}{|c|c|}
\hline $\begin{array}{l}\text { the CANTOS } \\
\text { study was } \\
\text { specifically } \\
\text { designed } \\
\text { to test } \\
\text { whether ... } \\
\text { canakinumab } \\
\text { could prevent } \\
\text { recurrence of } \\
\text { cardiovascular } \\
\text { events in } \\
\text { patients } \\
\text { with a ... } \\
\text { persistent pro- } \\
\text { inflammatory } \\
\text { response }\end{array}$ & $\begin{array}{l}\text { In the CANTOS trial, canakinumab, } \\
\text { a monoclonal antibody targeting } \\
\text { the IL-1 } \beta \text { innate immunity pathway, } \\
\text { significantly reduced the inci- } \\
\text { dence of recurrent cardiovascular } \\
\text { events in patients with myocardial } \\
\text { infarction compared with placebo. } \\
\text { Furthermore, canakinumab therapy } \\
\text { was associated with a reduction in the } \\
\text { occurrence of both fatal and nonfatal } \\
\text { lung cancers. These findings were } \\
\text { presented at the ESC Congress } 2017 \\
\text { and simultaneously published in } \\
\text { The New England Journal of Medicine } \\
\text { and The Lancet. } \\
\text { "Over } 25 \text { years, my group has } \\
\text { sequentially shown in human data } \\
\text { that biomarkers of inflammation such } \\
\text { as high-sensitivity C-reactive protein } \\
\text { (hsCRP) and IL-6 can predict heart } \\
\text { disease independent of traditional } \\
\text { risk factors; that statin drugs are } \\
\text { anti-inflammatory as well as lipid } \\
\text { lowering; and that we can prevent } \\
\text { heart disease in large populations } \\
\text { by targeting inflammation itself," } \\
\text { comments Paul Ridker, lead investi- } \\
\text { gator of CANTOS. To date, however, } \\
\text { no evidence existed to indicate that } \\
\text { reducing vascular inflammation in the } \\
\text { absence of lipid lowering can decrease }\end{array}$ \\
\hline
\end{tabular}

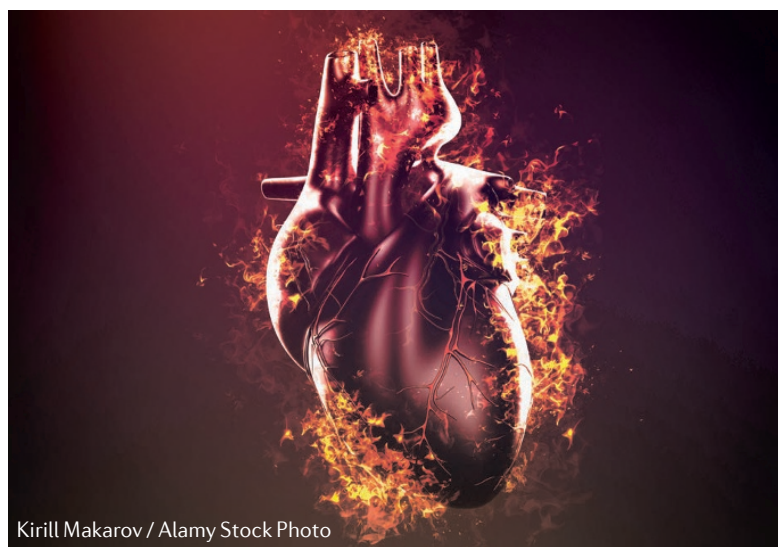

the occurrence of cardiovascular events. Given that IL- $1 \beta$ inhibition has been previously shown to lower IL-6 and hsCRP levels without reducing LDL-cholesterol concentration, the CANTOS study was specifically designed to test whether the antiIL- $1 \beta$ antibody canakinumab could prevent recurrence of cardiovascular events in patients with a history of myocardial infarction and a persistent pro-inflammatory response (defined as hsCRP $\geq 2 \mathrm{mg} / \mathrm{l})$. This randomized, double-blind, placebo-controlled trial included 10,061 patients who were randomly assigned to canakinumab (50 mg, $150 \mathrm{mg}$, or $300 \mathrm{mg}$ ) or placebo. The primary efficacy end point was nonfatal myocardial infarction, nonfatal stroke, or cardiovascular death.

At 48 months, hsCRP and IL-6 levels were significantly reduced in patients receiving canakinumab compared with placebo-treated individuals. However, no differences in LDL-cholesterol or HDL-cholesterol levels were noted between treatment groups. After a median of 3.7 years, the incidence of the primary end point was 4.50 events per 100 person-years in the placebo group and 4.11, 3.86, and 3.90 events per 100 person-years in the $50 \mathrm{mg}, 150 \mathrm{mg}$, and $350 \mathrm{mg}$ canakinumab groups, respectively. The $150 \mathrm{mg}$ and $300 \mathrm{mg}$ doses lowered hsCRP equally and both reduced heart attack, stroke, and cardiovascular death by $15 \%$. Notably, patients in the pooled canakinumab group were more likely to die from infection or sepsis than those in the placebo group (incidence rate 0.31 versus 0.18 events per 100 person-years; $P=0.02$ ).

Given the role of IL- $1 \beta$ in promoting tumour invasiveness, growth, and metastatic spread, the CANTOS investigators postulated that canakinumab might also reduce the incidence of cancer in their cohort of patients with atherosclerosis who were free of previously diagnosed cancer. This hypothesis was tested in a separate secondary analysis of the CANTOS trial.

After the median 3.7 years of follow-up, the pooled canakinumab group showed lower total cancer mortality and lung cancer mortality than the placebo group $(P=0.0007$ and $P=0.0002$ for trend across groups, respectively). In addition, the incidence of lung cancer was significantly lower in the $150 \mathrm{mg}$ (39\% reduction) and $300 \mathrm{mg}$ (67\% reduction) groups than in the placebo group $(P<0.0001$ for trend across groups).

"We now know definitively that IL- $1 \beta$ plays a fundamental role in atherosclerotic progression and that its inhibition can be achieved safely," concludes Ridker. "We have further demonstrated the critical importance of inflammation inhibition in lung cancer," he adds. "CANTOS is just the beginning; with this core proof nailed down, floodgates are already opening to see if we can achieve similar results in both cancer and cardiology with orally available agents."

Karina Huynh

ORIGINAL ARTICLES Ridker, P. et al. Antiinflammatory therapy with canakinumab for atherosclerotic disease. N. Engl.J. Med. http://dx.doi.org/10.1056/NEIMoa1707914 (2017) Ridker, P. et al. Effect of interleukin- $1 \beta$ inhibition with canakinumab on incident lung cancer in patients with atherosclerosis: exploratory results from a randomised, double-blind, placebocontrolled trial. Lancet http://dx.doi.org/10.1016/ S0140-6736(17)32247-X (2017) FURTHER READING Ruparelia, N. et al. Inflammatory processes in cardiovascular disease: a route to targeted therapies. Nat. Rev. Cardiol.14, 133-144 (2017) 